\title{
A BREAKTHROUGH SYLLABUS IN TEACHING LANGUAGE TESTING COURSE
}

\author{
TEDI ROHADI \\ triaincrbn@gmail.com \\ IAIN Syekh Nurjati Cirebon
}

\begin{abstract}
The word "testing or assessment" has always been a scarry thing for anybody especially students. This perception is worsened by the fact that time allotment of the course is limited and the scope of materials to be covered is overloaded. As a result, the students are overwhelmed, confused, and even frustrated. The paper is a report of a breakthrough syllabus in teaching language testing course resulted from a classroom action research in effectively transforming such frightening, bewildering, and discouraging nuances to be a conducive teachinglearning circumstance. Theories and concepts underpinning the study as well as research methodology will initiate the paper. The next part of the paper will discuss the so called "a breakthrough syllabus" itself as the focus of the study and its implementation and findings. The paper will not only elaborate some problems that were encountered during the implementation but also will provide some suggestions to anticipate those potential problems in the end part of the paper. The discussion last but not least enlighten every aspect involved in the study.
\end{abstract}

Keywords: Assessment, Syllabus, Language Testing

\section{BACKGROUND}

Language testing course, based on the interview and questionnaire given to students of English Education Department in IAIN Syekh Nurjati Cirebon, was considered to be one of the most difficult subjects. The difficulty stems from they way it was taught and unconducive students' perception due to the fact that first, the students were simply required to do presentation without sufficient explanation and no clear terminal and real objectives.from the lecturers; second, time allotment of the course is limited and the scope of materials to be covered is overloaded. As a result, the students are overwhelmed, confused, and even frustrated. In addition to the difficulties naturally emerging in the subject, the confusion of the lecturers of having no syllabus designed and provided by English Departement.led.students to the boredome and monotony which result in students' lack of motivation and bad result in their achievement..Therefore, there should have been a syllabus that could facilitate the lecturers to refer to when teaching and enhance students in understanding and applying language testing concepts in order to be able to design and produce a language test.

Syllabus and curriculum are often contrasted and used interchangeably. Nunan (1993: 8) defines curriculum as concerned with the planning, implementation, evaluation, management, and administration of education programs. However, syllabus has been perceived, interpreted, and defined in different ways during times..Nunan (1993:8) sees a syllabus as a process. Widdowson (1990:127) interprets a syllabus as the specification of a teaching.programme or pedagogic agenda and is concerned with both the selection and the 
ordering of what is to be taught. Candlin (1984) defines a syllabus as a means for encouraging learners to challenge the pedagogic ideologies and views of reality that the syllabus designer brings to the class..Brumfit (1984:75) defines a syllabus as a document of administrative convenience which will only be partly justified on theoretical grounds so as to be negotiable and adjustable. Yalden (1983:14) perceives that a syllabus replaces the concept of 'method', and the syllabus is now seen as an instrument by which the teacher, with the help of the syllabus designer, can achieve a degree of 'fit' between the needs and aims of the learner (as social being and as individual) and the activities which will take place in the classroom.

Two different contrasted types of syllabi are explored in this study. The first type is product-oriented and process-oriented syllabuses (Nunan,1988). Product-oriented syllabuses are those in which the focus is on the knowledge and skills which learners should gain as a result of instruction (the product or the end). Structural/formal, situational, lexical, and notional-functional syllabuses belong to these types of syllabuses. Process syllabuses are those which focus on the learning experiencing themselves (the processes toward the end). Task-based, procedural, negotiated, proportional, and content-based syllabuses are characterized to be process oriented syllabuses.

The second type is type A versus type B syllabuses (White,1988). Type A syllabi are concerned with what should be learned without considering who the learners may be. They are product-oriented, so they evaluate the outcomes in terms of mastery. Type B syllabi, on the contrary, are concerned with how the knowledge/skills is/are learned and how knowledge/skills is/are integrated with learners' experiences. The different elements of the syllabus emerge from a process of negotiation between learners and teachers; they are oriented toward the process; and evaluation criteria are set by the learners themselves. Procedural, process, and task-based syllabi are considered Type B syllabi despite their differences

A syllabus functions: first, to invite students to your course and to inform them of the objectives of the course and to provide a sense of what the course will be like; second, to provide a kind of contract between instructors and students - to document expectations for assignments and grade allocations; third to provide a guiding reference - a resource to which students and instructional staff can refer for logistical information such as the schedule for the course and office hours, as well as rationale for the pedagogy and course content.

Nunan (2003:71) enumerates eight information that have to be included in a syllabus: (1) learning objectives, (2) goal/rationale, (3) basic information such as: course name and number, meeting time and place, instructor name, contact information, office hours, instructional support staff information, (4) course content: Schedule, outline, meeting dates and holidays, major topics and sub-topics preferably with rationale for inclusion, (5) student responsibilities: particulars and rationale for homework, projects, quizzes, exams, reading requirements, participation, due dates, etc. Policies on lateness, missed work, extra credit, etc, (6) grading method: clear, explicit statement of assessment process and measurements, (7) materials and access: required texts and readings, course packs, how to get materials including relevant instructional technologies. Additional resources such as study groups, etc., (8) teaching philosophy: pedagogical approach including rationale for why students will benefit from it.

\section{METHOD}

This study is mainly intended to develop a syllabus as a guideline for the instructional activities which is later on implemented and evaluated in classroom teaching-learning processes during the whole semester. The stages in developing the syllabus are adopted and 
simplified from those of Borgs and Gall (2003) and Yalden (1987). They comprise of: (1) need survey, (2) description of purpose, (3) selection or development of syllabus type, (4) production of a proto syllabus, (5) production of a pedagogical syllabus, (6) development and implementation of classroom procedure, and (7) evaluation stage. The steps of research and development are described in the following table:

\begin{tabular}{cll}
\hline & Main Steps & \multicolumn{1}{c}{ Steps in Research and Development } \\
\hline $\begin{array}{c}\text { Preliminary } \\
\text { Research }\end{array}$ & $\begin{array}{l}\text { Research and Information } \\
\text { collecting }\end{array}$ & - Need survey \\
& Planning & - Description.of purpose \\
Research \\
$\begin{array}{c}\text { and } \\
\text { Developmen } \\
\mathbf{t}\end{array}$ & $\begin{array}{l}\text { Develop preliminary form } \\
\text { of product }\end{array}$ & $\begin{array}{l}\text { - Selection or development of syllabus } \\
\text { type }\end{array}$ \\
& $\begin{array}{l}\text { Field testing and product } \\
\text { revision }\end{array}$ & $\begin{array}{l}\text { - Production of a proto syllabus } \\
\text { - Evaluation stage }\end{array}$ \\
\cline { 2 - 3 } & & \\
\hline
\end{tabular}

Final Product Revision $\quad$ Final product of Syllabus

\section{FINDINGS}

\section{Grand Design of The Syllabus}

The syllabus is structured into several main parts: course details, course introduction, course objectives, course content, references, class schedule, course evaluation, and class attendance and policies. The first part of the syllabus structure is course details. It.covers what course title is, what course book is used, instructors complete name and email address..Course introduction as the second part of the syllabus explains a general overview what language testing offers and provides as a course study. The following part of the syllabus is course objectives. It shows the targeted objectives which are graded depending on level of cognitive domain. The class schedule as the fourth part of the syllabus is.most importantly featured since it shows how the syllabus is nuanced with various notions, approaches, and methods of learning and teaching. The next part of syllabus is course evaluation which shows the elements and the percentages of.grading system. The last part of the syllabus is class attendance and class policies which expose the rules and policies the students have to commit with.

The part of course objectives shows that the scope of the syllabus is limited. The limitation is based on the results of need analysis. All course materials to be covered are focused on how to assist students to be able to design and write a formative test.

The core part of the syllabus is featured mainly on class schedule because it posits varieties of.notions, approaches, and methods of learning and teaching. The class schedule is designed for sixteen (16) sessions devided into four lecturer-led sessions, mid and final term exams, and ten students-centered sessions. The students experience such a number of learning activities as lecturer led orientation to language testing principles, general overview of language testing, one to group simultaneous presentation, pair and group work, wrap up review, one to one student-lecturer consultation, mutual revising, and finally report presentation and submission.

In prelimanary orientation, lecturer plays dominant role since he/she has to brief the students concerning language testing course, class activities, task and assignment, and rule and regulation as well as class schedule. The activities in class are lecturing done by lecturer, 
note taking by students and discussion in the end part of the session. In addition, the students are grouped and assigned a chapter to be discussed and individually presented. Finally the lecturer models the activities that will be carried out through the whole semester.

On the second session, the lecturer gives general overview of language testing. It is intended to provide a basic framework of language testing perspectives. The students are supposed to be introduced with and made aware of language testing principles in relation to teaching constelation.

From the third to seventh sessions, the primary activities in classroom are mainly conducted by students by having one to group simultaneous presentation. It is different from the common presentation in which it is sequenced following the topics/chapters to be covered. In this presentation all and each.students are supposed to do presentation by presenting the chapter/topic assigned taking turn. At the same time the students are supposed to do note taking of what his/her classmate is presenting, pose prepared questions, and give evaluation to the overall presentation. After the session is over, the students have to write a learning journal about what he/she has got during the one to group presentation. The function of lecturer during these sessions is.monitor and ensure the activities to run as it is supposed to be as well as facilitate the students problems.

After the pair work presentation activities requiring four sessions, there will be a wrap up-review given by lecturer. It is intended to allign and benchmark all students understanding of all materials to be covered and to show interrelatedness of one concept, notion, theory to the one. Therefore, the students are expected to gain a thorough understanding of language testing.

The mid term session is individual review or concept checking activities in which lecturer requires the students to report orally regarding their understanding on overall topics. Up to this point, the lecturer can measure how effective the previous activities, and the students are required to show minimun understanding of basic language testing concepts otherwise they have to repeat. This activity is very essential because the students are prepared to be ready to do final project.

The following two sessions are the orientations.of conducting final. The purpose of these sessions is to provide students a practical guidance on how design a test. The test to be designed is restricted within classroom environment, focusing only on formative test. Not only does a lecturer give explanation on the tool kit, he/she provides a sample.of some formative tests.

After these sessions, the students work collaboratively to design the formative in such a way that one student is to be a collaborator and reviewer of his/her partner. Meanwhile the consultation can be done both with face to face consultation and with on-line via blog, email, or yahoo messengger. In this stage, the role of the lecturer is to manage the students in order to have sufficient access to him/her for consultation. The final activity is for students to submit their report on their simple mini research. Finally, there is no such formal final exam but a portfolio one. Final exam is carried out by providing and reporting all learning evidence the students have made from the beginning up to the end of course.

\section{DISCUSSION}

To start with, need.analysis was carried out as an indispensable aspect of syllabus design in order to meet the most current needs. Need analysis is given not only to the students but also lecturers as well as a.head of English Education Department. The development of a suitable syllabus to fulfill the need is essential. The focus of need analysis is to find out the existing problems, demands, and expectation of how and what to achieve in language testing course (Richards and Renandya, 2002:75). McKay (1978:11) uses the term in a special way 
in which it provides a focus for what should be studied, along with a rationale for how that content should be selected and ordered regardless of the approach a teacher adopts

The development of syllabus is conducted on the basis of Yalden's design named language program development (Yalden, 1987:88-90). It is selected for several reasons. First, it provides clearer and simpler steps by putting them in simple sentences and purposes as well as clear cyclical procedure to follow. Second, It provides syllabus content specification prior to writing the draft by developing proto-syllabus. Third, It covers the students' characteristics obtained through need survey. The model is a step-by-step procedure in developing a language program. It covers (1) need survey, (2) description of purpose, (3) selection or development of syllabus type, (4) production of a proto syllabus, (5) production of a pedagogical syllabus, (6) development and implementation of classroom procedure, and (7) evaluation.

The currents syllabus as the product of study can best be labelled to be a mixed syllabus (Brown, 1995:12). It adopts two types of syllabuses: notional and task based syllabuses. As a mixed syllabus, the materials organization of the syllabus is related to functional organizational and on occasion serves as a general set of categories within which functions form subcategories. It is organized around abstract notions of language testing concepts and theories which are ordered and sequenced according to chronology, frequency, or the utility of the notions involved. Furthermore, the syllabus.also organizes and sequences different tasks and assigment that the students are required to perform in and out of the classroom. The tasks and assignment are selected based on the perceived usefulness and interrelatednes not to mention the concordance with the learning approach adopted.

Teaching thinking skills is featured prominently in this new syllabus as there is a rising awareness of a lack of problem-solving and decision-making skills among school leavers and university students. Thinking is the ability to reason systematically with logic and evidence (Adu-Febiri, Francis, 2002). The major characteristics of this thinking syllabus are:.promote in-depth learning, revolve around real world tasks, involve a holistic approach to teaching thinking.

In promoting in-depth learning, important concepts and strategies have to be identified, organized and taught in detail and depth. This is to ensure that students are truly knowledgeable, where they do not only possess information but are able to apply and communicate this knowledge in the real world (Schwartz and Parks, 1994 and Fennimore and Tinzman, 1990 cited in Richards and Renandya, 2002). Students would have more time to think and engage in continous inquiry and complex thinking.

In this syllabus all tasks carried out in classrooms are related to each other and based on real world tasks and should encourage interdisciplinary thinking. Students are engaged in learning for life to be a teacher. There is connections between content and processes to the learners'background and needs, as this would relate school learning to real life (Schwartz, 2000 and Parks, 1994 \& Jones an Haynes, 1999 cited in Richards and Renandya, 2002). There would be more meaningful learning. Through these tasks and activities, there would be more collaborative teacher-student relationships and shared beliefs about thinking.

When involving holistic approach in the syllabus, students are engaged with a whole task and not elements of a task (Fennimore and Tinzman, 1990 cited in Richards and Renandya, 2002). Materials and content are structured to allow holistic learning of meaningful and complex tasks. There is much more flexibility, creativity and critical thinking in the classrooms.

The objectives of the syllabus is ranked based on Bloom's Taxonomy (Bloom \& Kratwohl, 1965) in which it starts from the lower level cognitive/thinking domain to higher ones beside affective domain. The syllabus prepares the students to be able to: first.develop an awareness of many of the sub-disciplines within the field of language testing; second,.gain 
a broad-based understanding of the key concepts within this field.and a better understanding of how language testing and other fields of study are related as well as a better understanding of the theoretical foundations underlying the field; third, become updated with the most current work in the field; fourth, link together the different areas of language testing study; fifth, design a language test; finally, become a cooperative member of a dynamic classroom.

In the case of classroom and learning strategies in this syllabus, flexible learning, creative and critical evaluation are encouraged in the classroom. There is a flexibility to allow more time for students to process their thoughts and voice their opinions. There is creativity in using various authentic and real-world teaching materials, such as the use of computers and new technology (Schwartz, 2000 and Schwartz and Parks, 1994 cited in Richards and Renandya, 2002). There is flexibility to allow students to be involved in the decision-making process of how they learn. This would enable them to eventually take control of their learning.

Thinking and learning strategies and cognitive and metacognitive strategies.are explicitly taught and modeled. Cooperative and collaborative learning take place through group work and group project (David et.al, 1991). Learning is linked to thinking. Thinking is transforming. Yet the transforming is the result not of surface learning but that of long term deep learning. Johnson, Johnson, and Smith (1991) stress that: " the use of collaborative learning groups approximates more closely the activity of real-world employment and problem solving... allows students to tackle more complicated and ofter more interseting problems without feeling overwhelmed."

When students are faced with the task of producing a solution to a problem, working in groups would enable them to produce richer and better quality solutions than would individual work..Student.collaboration is also carried out through virtual classroom which would eventually lead to improvements in the area of academic achievement as the students learn to interact, share information and devide workload. Bruffee (1989) stresses that:

"collaborative work provides the transitional support communities that students can rely on a they go through the risky process of taking on authority themselves as writers and critical readers. It provides measure of security as students subtitute confidence in their own authority for dependence on the teacher's authority."

Cockburn and Ross (1978) added that group work can train students to develop critical thinking skills,

"students learn in small groups through co-operative academic work and it is perhaps precisely the interactive element of small group work that brings about what can be called the higher order types of learning. By this we mean, for example, the development of judgement or interpretative skills. Cockburn and Ross (1978:22)

The result of adopting collaborative and cooperative learning in the syllabus reveals that learners can become collaborative constructors of their own knowledge and become independent and critical thinkers who are in control and are accountable for their own learning. In addition, the other learning concept adopted here is "problem-based learning (PBL)". It ensures that the learner leaves the educational experience a thinking independent individual. In.the PBL situation the entire dynamic of learning shifts from the hands of the teacher to the shoulders of the learner. Ownership which entails responsibility shift to the leaners.

Furthermore, the syllabus requires the students to write reflective journal. The.reflective journals allow teachers to assist learners to develop deep thinker skills. Journal in education are not new. They have been used for a long time now and they come in different packaging. 
Diaries, learning logs, learning journal, progress files, thinkbook, think place are all terms that have been used to describe the exercise if writing individual thoughts as part of a learning engagement.

The reason why it is important that journaling be part of the learning process especially in a PBL classroom is because much of the actual learning is self directed. Individuals have to discover new knowledge and then synthesise and evaluate the new knowledge to make group sharing meaningful (Wolf, 1989, Fulwire, 1986). Reflective journals allow learners to engage in self discovery. It allows them to open up and move on a learning continum from being passive to active learners. It also allows them to develop multiple thinking skills. The benefit are convincing.

While the benefits of any task in an educational endeavour cannot be dennied yet the task of journaling seems to have an edge especially when we realise that journaling actually satisfies the three ways of learning. The learner learns by doing (enactive), by using imagery (iconic) and by alluding to representational or symbolic means. The act of engaged writing ensures that all of these three aspects of learning are met. Journaling is thus a powerful tool to help move learners from learning by memorising (surface learning) to learning by owning (deep learning) (McCrindle \& Christensens 1995)

Regarding assessment, the syllabus encourages a thinking-learning environment which involves more application rather that regurgitation of facts. Therefore, assessment should be less exam oriented and be based more on on-going, real-world, collaborative assessment, such as project work. Students should also be provided with the opportunity to evaluate their learning through metacognitive strategies which would teach them how to control and manage their learning (Schwartz, 2000).

Reinventing or restructuring the syllabus to one that encourages thinking and develops a holistic approach to learning, is and will be one that involves massive changes and a rethinking of what teaching and learning should be. Implementating a thinking oriented curriculum would mean redesigning critical aspects of teaching, learning and schooling. These critical aspects that need to be addressed simultaneously and seriously, contain elements that interrelate and support thinking and learning. This process can only begin with a change in the beliefs and attittudes towards education, teaching and learning.

\section{Problems and.Anticipation}

The first problem that might be encountered during implementation of the syllabus is the differences in students' level of English. There will be some students that dominate others with their talkativeness and there will be some students who could not perform well in presenting materials. If meeting such situation, lecturer needs to give assistances so as to bridge the gap beside giving some guidance in how to conduct a good presentation..

The implementation of syllabus requires students to have some prerequisites such as a basic presentation skills for they have to.present the topic assigned and a writing skills for writing a journal. So, the lecturer should find out whether the students have taken writing course and obtained the course of how to deliver presentation, otherwise the lecturer should guide the studetns during their presentation activities and journal writing.

The lecturer when following the syllabus has to prepare all instruments ready for students such as a copy of syllabus, evaluation sheet, question log, and journal sheet. Lecturer is extremely demanded to spare a lot time in stage of individual review and scoring the students final project report.

This multi-tasking syllabus demands a commitment between students and lecturer. The commitment might be actualized in the form of learning contract so the students and lecturer commit to follow the procedure, rule and regulation, and activities embeded in the syllabus. 
Last but not least, national holidays and some unexpected events in and out of campus as well as academic calender should be anticipated to prevent the mismatch between the schedule. This syllabus requires a tight sequencial sessions.

\section{CONCLUSION}

This mixed type of syllabus as the product of research and development activities is multi-tasking in nature and mutli-loaded with such learning approaches as active, collaborativ-cooperative, and problem-based learning approaches, and is also enhanced with critical thinking. So the syllabus requires the students-lecturers' commitment to put into practice.

This syllabus has qualitatively shown some students learning improvement. Not only does the motivation of students improve but students has also got a kind of learning ownership. They have to be responsible of their own learning and performance. On top of that, The breakthrough syllabus has been able to effectively transform such frightening, bewildering, and discouraging nuances to be a conducive teaching-learning circumstance.

In implementing this syllabus, the lecturer.should be aware of how much time and how many efforts he/she has to spend within the semester otherwise he will come into a situation of burning out. Despite the merits the syllabus has proved, there have to be other studies to follow up to improve and complement the weaknesses on the research methodology and the products of this study.

\section{REFERENCES}


Adu-Febiri, F. 2005. "Beyond Knowledge and Skills: Bringing Emotions, Morals and Spirit into the Classroom." A Paper presented at the International Conference on Pedagogy, Nanyang Technological University, Singapore, May 30 -June 10, 2005.

Bloom, B.S. \& D.R. Kratwohl. (1965). The Taxonomy of Educational Objectives, The Classification of Educational Goals. Handbook 1: Cognitive Domain New York: D. McKay.

Brown, H. D. (2007). Principles of language learning and teaching (5th ed.). New York: Longman.

Brown, J. D. (1995). The elements of language curriculum. New York: Newbury House.

Bruffee, K.A. (1989). Thinking and Writing as Social Acts. In Thinking, reasoning and writing, ed. Maimon, P. Elaine, Barbara F. Nodine and Finbarr W. O'Connor. Pp. 213222. Longman Series in College Composition and Communication.

Brumfit, C.J. \& Johnson, K. (eds) (1979) The Communicative Approach To Language Teaching. Oxford: OUP.

Cockburn, B. \& Ross, A. (1978) Working Together. Teaching Higher Education Series: 3 School of Education, University of Lancaster.

Ellis, R. (1993). The structural syllabus and second language acquisition. TESOL Quarterly, 27, $91-113$

Fulwiler, T. (1986) Seeing with Journal. The English Record, 32 (3), pp 6-9.

Hutchinson, T. \& Waters, A. (1987) English For Specific Purposes: A Learning Centred Approach. Cambridge: Cambridge University Press.

Johnson, David W et.al. (1991). Cooperative learning: increasing college faculty instructional productivity. Washington: George Washington University.

Johnson,D,. Johnson, R \& Smith, K.A. (1991). Active Learning: Cooperation in the College Classroom, Edin, Minn.; Interaction Book Companya.

King, P and Kithener, K. (1994). Developing Reflective Judgement. Jossey-Bass, San Fransisco.

McCrindle, A. And Christensen, C. (1995). The Impact of Learning Journal on Metacognitive Processes and Learning Performance, Learning and Instruction, 5 (3): 167-185

Nunan, David. (2003). Practical Language Teaching. New York: McGraw Hill.

Prabhu, N.S. (1987) Second Language Pedagogy. Oxford: OUP.

Richards, Jack C and Willy A Renadya. (2002). Methodoly in Language Teaching: an Anthology of Current Practice. Cambridge: Cambridge University Press.

Richards, J.C. \& Rodgers, T.S. (1986) Approaches And Methods In Language Teaching. Cambridge: Cambridge University Press.

Speck, B. W. (2002). Learning-Teaching- Assessment Paradigms and the Online Classroom. In Assessment Strategies for the on-line class: from theory to practice, ed. Anderson, S. R., Bauer, J.F., Speck, B.W. Wiley Periodicals, Inc, USA. 19-30

Wolf, M. 1998. Journal Writing: a means to an end in educating students to work with older adults. Gerontology and Geriatrics Education, 10: 53-62..

Schwartz, B. L. (2000). Skirmishes in the memory wars: Review of Williams and Banyard's Trauma and Memory. Applied Cognitive Psychology, 14, 594 - 595.

Mackay, R., \& Mountford, A. (Eds.). (1978). English for Specific Purposes: A case.study approach. London: Longman..

Wetherell, J. And Mullins, G. (1996). The Use of Student Journal in Problem Based Learning, Medical Education, 30:105-11

White, R.V. (1988) The ELT Curriculum : Design, Innovation And Management. Oxford: Blackwell.

Widdowson, H.G. (1978) Teaching Language As Communication. Oxford: OUP. 
ISSN: 2579-8170 e-ISSN: 2549-5089

Widdows, S. \& Voller, P. (1991) "PANSI : a survey of the ELT needs of Japanese University students". Cross Currents 18, (2), 127-141.

Wilkins, D.A. (1976) Notional Syllabuses. Oxford : Oxford University Press.

Yalden, J. (1983). The communicative syllabus: Evolution, design and implementation. Oxford: Pergamon.

Yalden, J. (1987). The principles of course design for language teaching. Englewood Cliffs: Prentice-Hall 